\title{
How do income inequality and fiscal consolidation impact on banking crises? A post-Keynesian view
}

\author{
GUILLERMO PEÑA \\ Universidad de Zaragoza *
}

\begin{abstract}
This is the first paper in estimating a population-averaged panel logit probability model to test the importance of the interaction between deficit in the public budgeting and income inequality on banking crises, for 36 developed countries from 1961-2011. New empirical evidence is shown on whether rising inequality is linked with financial crises, corroborating theoretical expectations of post-Keynesian authors. Policy measures are provided and tested empirically: whilst in general terms higher levels of income inequality could be associated with financial crises; countries with high levels could reduce the likelihood of a crisis better in a context of fiscal consolidation. One reason could be that governments could use this public surplus for reducing income inequality, which helps to reduce defaults and banking crises. These results could be useful for academics, and policy-makers.
\end{abstract}

Keywords: Fiscal Consolidation, Income Inequality, Banking Crisis, Fiscal Policy

JEL Classifications: I32, H62, G01, E62

\section{Introduction}

Many papers have analyzed the post-Keynesian view that considers the influence of inequality on financial crises (Raghuram Rajan, 2010; Michael Kumhof, Romain Rancière, and Pablo Winant, 2015; Karolin Kirschenmann, Tuomas Malinen, and Henri Nyberg, 2016; inter alia). Nonetheless, Salvatore Morelli, and Anthony B. Atkinson (2015, p.31) state that "the overall evidence is far from being conclusive and there are several reasons to shed further light on this important research topic." In fact, none of them have empirically tested the impact of the interaction of income inequality, measured by the Gini coefficient, and public deficits as a determinant of banking crises in a panel logit model (Peña, 2016, 2017a). As far as known, this is the first paper in which, applying a panel logit model, income inequality and fiscal consolidation are interacted to study this issue.

\footnotetext{
*Assistant Professor at the Department of Economic Analysis. gpena@unizar.es.

I would like to thank the Editors and anonymous referees for their suggestions that have improved the paper.

(C) 2021 Guillermo Peña. Licensed under the Creative Commons Attribution - Noncommercial 4.0

Licence (http://creativecommons.org/licenses/by-nc/4.0/. Available at http: //rofea.org.
} 
The rest of the paper is divided into six sections. Section 2 provides the literature review, the definition of banking crises, the view of other schools about it and the determinants, consequences and policies for avoiding these crises. After having provided other angles, section 3 develops the post-Keynesian hypothesis of the paper in contrast to other perspectives. Section 4 explains data and methodology, using a multivariate logit panel data model and a System GMM to check it, whilst the empirical results are provided and discussed in Section 5. The main result of this section is the corroboration of the post-Keynesian view by a significant and robust positive impact of inequality on the likelihood of a banking crisis, jointly with the fact that fiscal consolidation is also beneficial for avoiding these crises. There is also contribution in policy measures, studying the impact of the interaction of income inequality and fiscal consolidation on banking crises. A negative sign of the coefficient of this variable is found, which gives a policy measure: establishing fiscal consolidation to reduce income inequality when a banking crisis starts. Finally, Section 6 provides conclusions, final remarks and further research. Additionally, there is an Appendix with other checks and estimations discarded by non-nest tests.

\section{Systemic Banking Crises}

First of all, it is required to provide a definition of systemic banking crisis (Dabrowski, Beyers and Villiers, 2016). A banking crisis could be defined as "the occurrence of simultaneous failures in the banking sector that significantly impairs the capital of the banking system as a whole, which mostly results in large economic effects and government intervention" (Lainà, Nyholm, and Sarlin, 2015), or as "a situation when more than half of the banking capital or at least a considerable share of the banking capital is lost" (Knutsen and Sjögren, 2009). Nonetheless, here we provide the definition of Laeven and Valencia (2020) for the update of the dependent variable employed in this paper. According to them, "we define a banking crisis as an event that meets two conditions: 1) Significant signs of financial distress in the banking system (as indicated by significant bank runs, losses in the banking system, and/or banking liquidations). 2) Significant banking policy intervention measures in response to significant losses in the baking system. We consider the first year that both criteria are met to be the year when the crisis became systemic."

After this definition, it is worth to separate the "banking crisis" from the "financial crisis". The former is a kind of the latter. Financial crises can be divided in banking crises, currency crises and sovereign crises. The first two ones are usually considered twin crises because they coincide (Kauko, 2014), as in the Nordic (early 1990) and Spanish (late 1970 and early 1980) crises (Reinhart, 2002). Nonetheless, as Balteanu and Erce (2018) state, there are also times in which banking and sovereign crises are combined.

According to the type of banking crisis, there are at least two types of banking crises regarding the evidence (Knutsen and Sjögren, 2009): insolvency crises as the crises in several 
PEÑA Income Inequality and Fiscal Consolidation

developed countries during the 1980s and 1990s without relevant outbreaks of bank panic or depositor runs, with widespread credit losses that lead to high amounts of non-performing loans, causing losses of capital and insolvency. Second, a combination of loan losses and depositor runs, as the "Asian flu" in 1997 (Kauko, 2014) where failing monetary policy was the main explanatory factor of bank panics and the crisis.

Now some prototype countries and their correspondent banking crises are going to be revised in order to see the main aspects that lead them to the brunt of the banking crises. First, it is worth to highlight the case of the Nordic countries, with the crises of Sweden (late 1870s), Norway (first half of 1920) and Finland (1990s), with the exception of Sweden. In all countries the banking crises were mainly driven by de-regulation and liberalization of the banking system in excess, encouraging the entrance of new banks and an excessive competition that put down their profitability. Some authors sustain that highly competitive markets lead to arise riskingtaking behaviors (Keeley, 1990), and that the monopoly power of banks is stabilizing (Noy, 2004). Beck et al. (2006) obtain that more concentrated banking systems are less vulnerable than atomistic ones, after controlling with institutional variables such as financial openness and economic freedom. For this case of Nordic countries, Knutsen and Sjögren (2009) contribute with an explanation, stablishing that all banking crises are preceded by an institutional clash as the de-regulation of these countries, defined as "a substantial shift of the dominating macroeconomic policy attached to the financial system". Excessive regulation could also lead to crises.

Gavin and Hausmann (1998) provide further examples. According to them, previous countries also experienced an adverse terms-of-trade shock before to the bank crisis (with the exception of Sweden), in addition to being the origin of the cases of Spain (80s, 90s) and most Latin American crises. Other causes were the exposition to volatility of the asset prices, as precedent of the failure of many banks in Argentine in the early 1995 by the Tequila effect for being exposed to Mexican banks; a long period of exchange-rate overvaluation and high interests as before the Chilean crisis of 1982-1983 or unstable macroeconomic and financial policy that unchained the 1980 financial panic in Argentina.

There are other policies that are involved in banking crises, for instance fiscal policy. Rising public expenditure while the currency is overvalued was the germen to the Tequila crisis at Mexico in 1995. Expansive fiscal and monetary policy led to a banking crisis. This kind of policies can also generate sovereign crises. But regarding banking crises, volatile fiscal policies can also hurt the banking system, generating destabilizing increases in the interest rates and, through the expectations of inflation, also unchaining fluctuations in deposit demand, as Gavin and Hausmann (1998) state. In addition, tax payers assume responsibility when the crash is large enough to require a bailout. This can also affect to income distribution, where savers can loss their savings and also have to pay more taxes, in contrast to high-income individuals that easily elude the tax system. In addition, tax elusion and avoidance could also deteriorate public 
accounts and lead the public sector to demand more public debt, sometimes provided by banks, and easing possible sovereign crises with the potential banking crisis. In Latin American countries there is plenty of corruption, tax avoidance and scarce economic freedom, which encourages banking crises. In general, fraud is a root of crises since lending can be used to circumvent regulation and there can be transfers of deposits to hold companies that are ruined, as occurred in the Turkish banking crisis of 2000 (Soral, İşcan and Hebb, 2006). According to Pereira et al. (2018), low level of GDP and high debt influence on banking crisis. Also during credit booms there could be higher income inequality because just before the outbreak of a crisis the economy grows at a speed higher than the average (Reinhart, 1999) and not always in the most pro-equality way. In fact, credit booms precede to most of the financial crises as in Argentina (1981), Chile (1981-82), Uruguay (1982), Colombia (1982-83), Norway (1987), Sweden (1991), Finland (1991-92), Japan (1992) and Mexico (1995), for citing some (Gavin and Hausmann, 1998).

There are other crises of interest. For instance, low interest rates lead to the Japanese crisis in the 1990s, or the sub-prime crisis and the Lehmann-Brother bankruptcy, with origin in the USA, led to the Global Financial Crisis (GFC) in the late 2000s due to financial contagion and the consequent Great Recession (GR) in the earlies 2010s. Fell et al. (2018) have highlighted the importance on reducing the levels of Non-Performing Loans (NPLs) in European countries (raised after the GFC and being currently at an average level of 3\% at Europe (EBA; 2020) in order to avoid the possible adverse impacts on financial intermediation. NPLs are "loans where the borrower - either a company or a physical person - is not able to repay a bank loan ${ }^{1} . "$

The roots and causes of banking crises are several. They can be divided into policy, macroeconomic, banking and institutional origins. Regarding the determinants related to policy, Goldstein and Turner (1996) highlight the heavy involvement of the government and the loose of controls on connected lending, Gavin and Hausmann (1996) point the volatile fiscal policy as a source or incorrect monetary policy, as previously mentioned, highlighting the effects of money supply or the interest rates (Frankel and Saravelos, 2012). Large fiscal deficits can predict crises while central bank independency prevents them (Kauko, 2014). Laeven (2011) focuses on the role of government subsidized housing policies as a generator of real estate booms or the potential procyclicality of fair value accounting. Respect to the macroeconomic factor, it is worth to highlight the macroeconomic volatility, external and domestic (Goldstein and Turner, 1996), terms of trade or world interest rates (Gavin and Hausmann, 1996), Gross Domestic Product (GDP), factors regarding current account, inflation, capital flows, external debt and financial openness (Frankel and Saravelos, 2012).

Referring to the banking influences, lending booms, asset price collapses and surges in capital flows are relevant (Goldstein and Turner, 1996), as well as rising bank liabilities with

${ }^{1}$ https://ec.europa.eu/commission/presscorner/detail/bg/MEMO $18 \quad 310$ 
PEÑA Income Inequality and Fiscal Consolidation

large mismatches in maturity or in currency (Goldstein and Turner, 1996), serious credit crunches, bank leverage, illiquidity, presence of information problems, interaction between bank solvency and liquidity, the inefficient payment mechanism, protection of depositors, with the explicit government-provided deposit insurance, low quality and riskiness of the assets, the role of debtors and government in a bankruptcy (Gavin and Hausmann, 1996), equity returns or debt composition (Frankel and Saravelos, 2012), the banking sector-relevant structural factors, as the too-big-to-fail or excessive banking competition (Kauko, 2014). Finally, institutional causes could be, as Goldstein and Turner (1996) asserts, the inadequate preparation for financial liberalization, the weakness in the accounting, disclosure and legal framework, exchange rate regime or the distorted incentives for bank owners, managers, bank depositors and for supervisors. Additional institutional factors are the absence of an appropriate framework for bank supervision and regulation as in most cases of Latin America, the limits of banking regulation regarding costs, absence of the enough information by the authorities or the need of a transparent prudential regulation (Gavin and Hausmann, 1996), the deregulation and fraud as root of several banking failures (Laeven, 2011).

The main consequences of banking crises are provided by Laeven (2011). These crises usually have real consequences, as decreasing output and employment, rising public debt, sharp decrease on the confidence in the banking system as a whole, losses from other (domestic or foreign) banks that were exposed to the bank fails, and losses in assets. There is also an immediate decline in the flow of credit to the real economy, unchaining and amplifying the negative effects to the borrower's wealth with presence of asymmetric information. There are also income inequality effects as transfers from taxpayers to banks when an insolvent bank is recapitalized or from savers to creditors when there is inflation or currency depreciation as a consequence.

For preventing or solving these crises, there are also certain policies. Addressing emerging liquidity loans, liquidity support, extensive guaranties on bank liabilities, bank holidays, regulatory capital forbearance, temporary assumption of executive powers by authorities, imposition of closes or merges with other financial institutions, workouts of distressed assets, restructure of debt or recapitalizations and nationalizations of banks are only some of the possible policies (Laeven, 2011). Other authors provide additional ones: reducing or living with uncertainty or volatility, adequate macroeconomic policies, reserve and variable capital requirements, supervisory tools (Goldstein and Turner, 1996 and Rathore, 2020) or improving the settled Value at Risk (VaR) models used in banking (Evangelos and Samitas, 2020).

\section{Development of Hypotheses}

Several economists consider that income inequality is correlated with financial crises (Rajan, 2010; Robert B. Reich, 2010; Kumhof, Rancière and Winant, 2015; Kumhof et al., 2012; James 
K. Galbraith, 2012; Palley, Thomas I., 2012).2 The reason is given by Till Van Treeck (2014, p.1):

As the benefits of rising aggregate income over the past decades were confined to a rather small group of households at the top of the income distribution, the consumption of the lower and middle income groups was largely financed through rising credit rather than rising incomes. This process was facilitated by government action.

These previous authors could be more or less related to Post-Keynesian school. Nonetheless, other authors find an insignificant relationship. In fact, other theories or thinking schools are not focused on inequality, sometimes even avoid involving in this topic. Regarding their view about banking crises, for instance, there is the theory of the efficient markets, where markets efficiently reflect the true prices of the products, showing all the information. The monetarist approach considers that banking crises are due to money, while the "business cycle school" links the crises to the business cycle. According to Knutsen and Sjögren (2009), mainstream considers problems related to the asymmetry in information combined with the presence of macroeconomic shocks, so there is a mixture of the previous two views. Laidler (2009) contrasts the monetarist approach that considers the excess of demand for money that the central bank has to relieve is a feature in banking crises, while later Wicksellian tradition sustains that central bankers have to avoid the intertemporal discoordination in the allocation of resources. On the other hand, Bianco and Sardoni (2018), shows the view of an additional school, the New Keynesian, who focus on the imperfections and frictions in the real sector and financial markets. In this case, income inequality could be considered as a friction in their view.

Other authors consider banking crises provoke income inequality, and not the opposite. According to Atkinson and Morelli (2011), nowadays the relationship may work in the opposite direction. On the one hand, pressures for fiscal consolidation may encourage a constant decrease of the welfare state. On the other hand, for the authors the avoidance of banking crises may be necessary to warrant the sustainability of the social institutions we have developed to control inequality, the welfare state and the stability of the governance. Atkinson and Morelli (2011) find that higher income inequality seems not to precede banking crises, but they find more evidence on the opposite: income inequality is preceded by banking crises. Jesper Roine, Jonas Vlachos, and Daniel Waldenström (2009) use data during the period 1900-2000 for 16 countries and they conclude that a financial crisis would reduce the top 1 percent income share by roughly 0.2 percentage points for each year of the crisis. The results of Michael D. Bordo, and Christopher M. Meissner (2012) suggest there is no significant relationship between inequality and credit booms. Using data from 14 advanced countries between 1920 and 2000, they obtain these are not general relationships. They find credit booms heighten the likelihood of a banking crisis. Nevertheless, they find no evidence that a rise in top income shares leads

\footnotetext{
${ }^{2}$ For a review of the literature about this link, see Rémi Bazillier and Jérôme Hericourt (2017).
} 
PEÑA Income Inequality and Fiscal Consolidation

to credit booms. Instead, the only two robust determinants of credit booms in their data set are economic expansions and low interest rates. Hence, they do not find evidence for the inequality, credit, crisis nexus, but a traditional boom-bust pattern of reductions in interest rates, excessive growth, increasing credit, asset price booms and crises.

First, this paper will check whether there is evidence that financial crises are preceded by income inequality, measured by the Gini index, and fiscal consolidation, in a separate way. Income inequality is considered because, as Luca Agnello, and Ricardo M. Sousa (2012, p.1425) state, "inequality increases before banking crisis episodes and sharply declines afterwards." Being aware other determinants of financial crises, we follow the post-Keynesian view of considering inequality as a determinant of financial crises and formulate a theoretical hypothesis:

H: "Income inequality and public deficits increase the risk of a banking crisis. A policy for reducing banking crises would be establishing public surplus for reducing income inequality when the crisis arrives. So, the interaction between fiscal consolidation, and income inequality lagged two years for reflecting the adaptation of income inequality thanks to the surplus, would reduce the likelihood of a banking crisis."

This last view would not be opposed to the New Keynesian view of the presence frictions, in this case the proposed policy would seek for eliminating a friction in the real sector, the interaction between sovereign deficit and income inequality. Previous-to-crisis surpluses would offset after-crisis deficits, maintaining the public budgeting balance in long term. From the monetarist and mainstream angle, this interaction can also be seen as a macroeconomic shock. According to the Wicksellian view, this can be a discoordination in the allocation of the resources that generates income inequality and crises; but could be solved by correctly employing a sovereign surplus.

In addition, there are, at least, two main reasons for supporting this hypothesis. First, some authors have highlighted the importance of the expansion of credit on banking crises (Taylor, 2009; Peña, 2017b) or the importance of tax policy (Peña, 2020). Nonetheless, fiscal consolidation and credit expansions are correlated (so, in the proposed econometric model, the latter variable will not appear), as Ağca and Igan (2019) show: higher fiscal consolidation turns into a cost of credit, overall for small businesses. So, fiscal consolidation could be considered a factor for reducing banking crises. On the other hand, public deficits, but also income inequality, lead to higher instability, due to temporary breaking the balance budgeting rule. Second, fiscal consolidation has distributional effects (so, income inequality will be lagged two periods in the model to clearly avoid multicorrelation, endogeneity and to show the higher income inequality previous to the fiscal consolidation) as Ball et al., (2013) show, therefore, the interaction between fiscal consolidation and income inequality lagged two years would reduce the risk of a banking crisis. 
Respect to the impact of income inequality on banking crises, jointly with the instability provoked by public deficits, is relevant to highlight that the higher the income inequality in a country, the less middle income people and the most lower income people would be, who could start to fall in credit default and encourage to a banking crisis.

As Roy and Kemme (2012, p.274) suggest, "Consistent data on Gini ratios or other similar measures are not readily available" for datasets as the one of this paper. This may be a reason for, as far as known, nobody has ever estimated a panel logit probability model explanatory of banking crises using the Gini index and the public deficit interacted.

\section{Data Sample and Methodology}

Our dependent variable, crisis, is available in the World Bank and represents a dummy variable that is 1 if the country is experiencing a banking crisis and 0 if not. We estimate the equations using a population-averaged panel logit probability model, as Büyükkarabacak and Valev do (2010).

$$
\operatorname{logit} \operatorname{Pr}\left(\operatorname{crisis}_{i t}=1 \mid \text { control }_{i t}\right)=\beta^{*} \operatorname{control}_{i t}
$$

The dependent variable is crisis, control $_{i t}$ are the control and target variables, $\beta^{*}$ the change in the logit of the proportion with crisis $=1$ for a raise in control of a unit.

Panel data is used, specifically, an unbalanced panel from the year 1961 to 2011 from 36 countries, all the EU (27) and some of the OECD countries according to Table 1, which gives some basic information about data.

The variable that represents income inequality, measured by the Gini coefficient, is lagged for two periods, in order to avoid reciprocity and simultaneity problems (Büyükkarabacak and Valev, 2010). The reason is that banking crises also impact on income inequality (Agnello and Sousa, 2012), as well as fiscal consolidation (Ball et al., 2013). The source of the data was the World Bank Database, except gini2, which comes from the databases of Eurostat and OECD, and distance, from the GeoDist Database (Thierry Mayer and Soledad Zignago, 2011).

Table 1. Countries and Years in the Sample

\begin{tabular}{|l||l|}
\hline Years: 52 & Countries: 36 \\
\hline \hline $1961-2011$ & Australia, Austria, Belgium, Bulgaria, Canada, Chile, Czech Republic, \\
& Denmark, Estonia, Finland, France, Germany, Greece, Hungary, Ireland, \\
& Iceland, Israel, Italy, Japan, Korea, Luxembourg, Latvia, Mexico, Lithuania, \\
& Netherlands, New Zealand, Norway, Poland, Portugal, Slovak Republic, \\
& Slovenia, Spain, Sweden, Turkey, United Kingdom, United States. \\
\hline
\end{tabular}


PEÑA Income Inequality and Fiscal Consolidation

Table 2. Summary Statistics.

\begin{tabular}{|c||c|c|c|c|c|}
\hline Variable & Observations & Mean & $\begin{array}{c}\text { Standard } \\
\text { Deviation }\end{array}$ & Minimum & Maximum \\
\hline \hline crisis & 1836 & 0.083 & 0.276 & 0 & 1 \\
\hline balance & 1632 & -0.348 & 6.548 & -34.68 & 32.268 \\
\hline terms & 1527 & $7.04 \mathrm{E}+11$ & $6.09 \mathrm{E}+12$ & $-3.58 \mathrm{E}+13$ & $6.97 \mathrm{E}+13$ \\
\hline exch & 1489 & 87.256 & 237.406 & 0.00001 & 1909.439 \\
\hline surplus & 575 & -1.546 & 4.351 & -29.42 & 20.01 \\
\hline lerner & 535 & 0.185 & 0.118 & -1.609 & 0.503 \\
\hline dist & 1,872 & 9.844 & 0.25 & 9.653 & 10.670 \\
\hline gini2 & 428 & 29.43 & 10.22 & 0.283 & 56.210 \\
\hline
\end{tabular}

Table 3 shows each variable with its respective source, and the expected sign of the coefficients of the control and target variables, as well as its references, based on the arguments of Sections 1 and 7. The effect of surplusgini2 on the dependent variable will be discovered empirically and discussed theoretically in Section 6.

Correlations among independent variables used in the model are shown in Table 4 . Variables with a high correlation are not included in the models and hence, in the matrix. Some variables were omitted due to a high correlation with other variables. Avoiding these variables, the highest one is the correlation between dist and gini2, with a value of 0.3 . This correlation is below 0.5 , so it does not seem to be multicollinearity problems. In spite of that, a VIF test has checked the presence of this problem among these variables and the results indicate these variables are far from multicollinearity.

Table 3. Expected Signs of the Variable Coefficients.

\begin{tabular}{|c|c|c|c|}
\hline Variable & Source & Sign & References \\
\hline balance & World Bank & 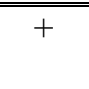 & $\begin{array}{c}\text { Rose and Spiegel }(2010,2011) \text { and } \\
\text { Stockhammer }(2013)\end{array}$ \\
\hline terms & World Bank & + & Hardy and Pazarbaşioğlu (1999) \\
\hline exch & World Bank & - & Hardy and Pazarbaşioğlu (1999) \\
\hline surplus & $\begin{array}{l}\text { World Bank } \\
\text { World Bank }\end{array}$ & - & $\begin{array}{l}\text { Demirguc-Kunt and Detragiache } \\
\text { (1998) }\end{array}$ \\
\hline lerner & World Bank & + & Beck et al. (2006) \\
\hline dist & $\begin{array}{c}\text { Mayer and } \\
\text { Zignago (2011) }\end{array}$ & - & Ye and Han (2010) \\
\hline gini2 & $\begin{array}{c}\text { OECD and } \\
\text { Eurostat databases }\end{array}$ & + & $\begin{array}{c}\text { Stockhammer (2013) and Wisman } \\
\text { (2013) }\end{array}$ \\
\hline
\end{tabular}


Review of Economic Analysis 13 (2021) 89-114

Table 4. Correlation Matrix of Independent Variables

\begin{tabular}{|c||c|c|c|c|c|c|c|}
\hline & balance & terms & exch & surplus & lerner & dist & gini2 \\
\hline \hline balance & 1 & & & & & & \\
\hline terms & 0.011 & 1 & & & & & \\
\hline exch & 0.132 & 0.101 & 1 & & & & \\
\hline surplus & 0.23 & 0.107 & 0.058 & 1 & & & \\
\hline lerner & -0.169 & 0.042 & 0.039 & 0.197 & 1 & & \\
\hline dist & -0.278 & -0.044 & 0.144 & -0.243 & 0.18 & 1 & \\
\hline gini2 & -0.011 & -0.054 & 0.218 & 0.035 & 0.035 & 0.305 & 1 \\
\hline
\end{tabular}

The variables are described as follows. The variable crisis is the dummy variable that takes the value 1 if there is a systemic banking crisis or 0 otherwise, the variable terms shows the terms of trade of the country defined as the capacity to import less exports of goods and services, exch reflects the exchange trade of a country, the variable surplus is the cash surplus (if it is positive) or deficit (if it is negative) of the government of a country, lerner is the degree of concentration of a banking system measured by the Lerner index, dist is the logarithm of the geographical distance of a country to the countries France, the USA and Japan that are economic potencies, measuring the avoidance of the contagion effect. Finally, gini2 is the degree of income inequality measured by the Gini index and lagged two years in order to avoid possible correlation, simultaneously and endogeneity problems. This variable is made using the Eurostat source for European countries and the OECD source for the rest.

The estimation procedure is as follows. First, a general model with the main variables regarding policy, macroeconomic and banking, and institutional factors was developed (including more than the variables of Table 2, see the Appendix). Nonetheless, there were too many variables for achieving convergence in the model and enough robustness, so a first division was needed to be made. Three kinds of models were developed, all of them starting with the target variables surplus, gini2 and their interaction. In addition, for each of the three models were chosen policy, macro and banking, and institutional variables, respectively, mainly understanding policy variables as those that the public sector could manage in the short run by developing direct or indirect policies, and institutional factors as those of the long run. Macroeconomic and banking variables are those regarding the specific characteristics of the economy of the country or the banks.

Once this is done for logit models, the next step is to sequentially eliminate from the model the variables with less significativity, until all the coefficients have a p-value of 0.15 or less, obtaining a reduced logit model. After that, and in order to avoid potential endogeneity bias, to dynamize and to robustly check the econometric specification of the previous models, System 
PEÑA Income Inequality and Fiscal Consolidation

GMM models are estimated. After this, the same sequence of variable-elimination is performed until a final model is obtained. Next, a logit model with the same explanatory variables as this final model is estimated, and there will be a test of non-nested models by checking the AIC and BIC tests, which are compared between these models and their correspondent previous reduced logit (obtained by eliminating non-significant variables starting from the logit model with all the variables of the same type). Therefore, a "finalist" model is obtained by choosing the one with the lowest AIC and BIC for each logit models of the same type of determinants of banking crises.

Following, there is an estimation of a logit model with all the variables of the reduced logit models (finalists or not) in order to apply the same eliminating-procedure and to obtain a reduced logit model based on an initial logit model with the full significant explanatory variables of the other models. There is also a GMM System estimation by the same procedure and giving the specification to an additional reduced logit model. As previously, the reduced logit model with the lowest AIC and BIC indicators is chosen as finalist.

Finally, among the finalists a definitive model will be chosen between the four finalist models (among the three finalists for each kind of determinant and the one parting from the full logit model with all the significant main variables) according to their AIC and BIC. To the nonreduced form of this definitive model (meaning the initial logit model without making the eliminating-procedure) there will be included as explanatory two additional variables in order to introduce dynamicity and to check the robustness of the results: a variable made by any lag of the dependent variable and geographical variables, giving the "complete" model. The eliminating-procedure will be applied to this model, leading to the second definitive model. Finally, the AIC and BIC indicators will be compared from the complete and two definitive models in order to obtain the chosen specification of the model. These last models will be exposed in the next section, while the other models and some other results will be shown in the Appendix.

\section{Empirical Results, Discussion, and Policy Measures}

The main results are found in Table 5 (p-value in italics below coefficient), showing the impacts of the target and control variables on the probability of a banking crisis. Model (I) is the definitive logit model estimated, and has good econometric properties, as joint significance of the parameters, based on a p-value of the Wald test that equals to zero. Model (II) is the robustness check model, which also have good statistical properties. Both the signs and the amount of the coefficients of the explanatory variables are equal or similar in both models. In Models I and II, the post-Keynesian thesis ${ }^{3}$ that inequality increases the risk of a banking crisis

\footnotetext{
${ }^{3}$ This seems to be the most interested school in the influence of income inequality on banking crises.
} 
is assessed, jointly with the impact of fiscal consolidation alone. Model (II) was estimated on the base of model (I), consecutively eliminating non-significant variables to obtain a simpler and more explanatory model, and keeping interest variables in the successive estimations.

Table 5. Definitive Estimated Models.

\begin{tabular}{|c|c|c|c|c|c|c|}
\hline crisis & (I) & (II) & (III) & $(I V)$ & $(\mathrm{V})$ & $(V I)$ \\
\hline \multirow[t]{2}{*}{$\operatorname{lag}^{a}$} & & & & & $2.8 * * *$ & $2.303 * * *$ \\
\hline & & & & & 0 & 0 \\
\hline \multirow[t]{2}{*}{ balance } & $0.185 * *$ & $0.209 * *$ & $0.174 * *$ & $0.209 * *$ & 0.058 & $0.167 * *$ \\
\hline & 0.014 & 0.04 & 0.039 & 0.042 & 0.277 & 0.010 \\
\hline \multirow[t]{2}{*}{ terms } & $9.72 \mathrm{E}-14 *$ & & $7.9 \mathrm{E}-14 *$ & & $9.67 \mathrm{E}-15$ & \\
\hline & 0.075 & & 0.081 & & 0.798 & \\
\hline \multirow[t]{2}{*}{$e x$} & $-0.004 * *$ & $-0.005^{*}$ & -0.003 & -0.004 & -0.001 & $-0.004 * *$ \\
\hline & 0.036 & 0.055 & 0.169 & 0.111 & 0.349 & 0.049 \\
\hline \multirow[t]{2}{*}{ surplus } & $-0.2 * *$ & $-0.215 * * *$ & 0.61 & & $0.58 *$ & \\
\hline & 0.019 & 0 & 0.119 & & 0.068 & \\
\hline \multirow[t]{2}{*}{ lerner } & -4.332 & & -5.522 & & -4.416 & \\
\hline & 0.252 & & 0.192 & & 0.243 & \\
\hline \multirow[t]{2}{*}{ dist } & $-0.557 * *$ & $-0.609 * * *$ & $-0.442 * * *$ & $-0.564 * * *$ & $-0.589 * * *$ & $-0.547 * * *$ \\
\hline & 0.001 & 0 & 0 & 0 & 0 & 0 \\
\hline \multirow[t]{2}{*}{ gini2 } & $0.131 * * *$ & $0.120 * * *$ & $0.096 * *$ & $0.105 * * *$ & $0.108 * * *$ & $0.09 * * *$ \\
\hline & 0.010 & 0 & 0.011 & 0 & 0.007 & 0 \\
\hline \multirow{2}{*}{ surplusgini2 } & & & $-0.025 * *$ & $-0.007 * * *$ & $-0.023 * *$ & $-0.006 * * *$ \\
\hline & & & 0.042 & 0 & 0.032 & 0.001 \\
\hline \multirow[t]{2}{*}{ core $^{\mathrm{b}}$} & & & & & $1.419 *$ & \\
\hline & & & & & 0.064 & \\
\hline $\begin{array}{c}\text { No } \\
\text { observations }\end{array}$ & 167 & 198 & 167 & 198 & 167 & 198 \\
\hline No groups & 28 & 29 & 28 & 29 & 28 & 29 \\
\hline $\mathrm{AIC}^{\mathrm{c}}$ & 123.04 & 145.614 & 119.574 & 145.249 & 108.346 & 132.902 \\
\hline $\mathrm{BIC}^{\mathrm{c}}$ & 144.866 & 165.343 & 144.519 & 164.979 & 139.526 & 155.92 \\
\hline Wald & 107.38 & 40.13 & 102.14 & 43.09 & 286.46 & 99.83 \\
\hline $\begin{array}{l}\text { Wald p- } \\
\text { value }\end{array}$ & 0.000 & 0.000 & 0.000 & 0.000 & 0.000 & 0.000 \\
\hline
\end{tabular}

* Significance level of less than $10 \%$, ** significance level of less than $5 \%$, *** significance level of less than $1 \%$.

a: In the logit model it has only been possible to use lags of two periods due to the lack of convergence with one period.

b: Germany, Great Britain, Netherlands, Luxembourg, Denmark, Norway, Sweden and Finland.

c: For obtaining the corresponding AIC and BIC estimators, it has been necessary to estimate the equivalent model in random effects. 
PEÑA Income Inequality and Fiscal Consolidation

As seen in the models, income inequality is correlated with the triggering of a banking crisis in a statistically significant and robust way, confirming the post-Keynesian view ${ }^{3}$ of Stockhammer (2013) and others. Part of the hypothesis of Section 3 is also corroborated. All variables with a robust and significant effect on the likelihood of a financial crisis have the expected sign: the external balance, with a positive sign, because raising the external balance is a reaction to a potentially paralyzed demand. This result is coherent with Rose and Spiegel $(2010,2011)$ and Stockhammer (2013). The sign of the coefficient of the terms of trade variable is positive and the exchange rate is associated to a coefficient with negative sign (that is, the adverse terms of trade and a shock appreciation of the national currency are associated with a banking crisis), as Hardy and Pazarbaşioğlu (1999) find. The prediction of Demirguc-Kunt and Detragiache (1998) that fiscal deficit provokes financial crises is corroborated, as well as another part of hypothesis of Section 3. As Section 3 also shows, first, fiscal deficit involves postponing measures to strengthen bank balance sheets and is an impediment to successful financial liberalization, which creates problems for banks. Second, a failure to control the budget deficit is an impediment to successful financial liberalization, which creates problems for banks. The lack of banking competition is obtained with a negative coefficient, in contrast to Gavin and Haussmann (1996) expectations, but it is not statistically significant. The variable dist, which reflects the geographical distance of a country to France, the USA and Japan, reduces the likelihood of a banking crisis, as Ye and Han (2010) expected. A nearer distance reflects higher risk of contagion of banking crises.

Taking into account the results of the paper, it is important to consider the following policies in order to avoid the risk of a banking crisis. For instance, is there any measure of fiscal consolidation related with the level of income inequality? Above we saw that the fiscal consolidation is a general rule to avoid banking crises. Nevertheless, we want to know whether it is always true or it depends on the level of inequality. To answer this question, in Model (III) the variable surplusgini2 is incorporated to Model (I) in order to find the impact of the interaction of income inequality and fiscal consolidation on the probability of a banking crisis. Finally, Model (IV) allows a robustness check of Model (III) by consecutively eliminating nonsignificant variables on the base of Model (III) and keeping interest variables in the successive estimations in order to obtain a simpler model and to check robustness. Model (V) checks the results by including a lag of the dependent variable by adding dynamicity and avoiding endogeneity, and also a geographical dummy variable, core, which considers countries where among them there have been crises the last decades (Nordic countries). Model (VI) is obtained reducing the previous one.

A robust and significant negative impact of the interaction term on the likelihood of a banking crisis is observed and a no significant impact of the variable surplus alone. This can be interpreted as follows: fiscal consolidation policies in order to avoid financial crises are more effective in countries with high income inequality than in the other ones. One reason can be 
that governments could use this surplus to face income inequality, reducing the likelihood of banking crises.

On the one hand, the no significant sign of the coefficient surplus alone show that fiscal consolidation per se does not seem to reduce the likelihood of banking crises. On the other hand, the negative sign of the interaction coefficient indicates that a fiscal consolidation in a lower income inequality country provokes a lower reduction of the crisis risk than in a higher one with the same level of surplus and ceteris paribus.

Another reason could be that households of countries with high income inequality are also highly indebted (Aldo Barba and Massimo Pivetti, 2009). Hence, high income inequality countries have to prevent more than low income inequality countries from possible banking crashes due to bad debts. If fiscal consolidation is settled, banks with bad debts would be more easily rescued by the governments, and then the probability of a crisis would be reduced. This paper is also based on Leonard E. Burman et al. (2010) and others, who state that the fears of investors about future deficits (due to households' bad debts, in this case) can trigger a financial crisis. Jesús Ferreiro et al. (2016, p.213) shows a kind of policy rule when they state:

Any strategy of fiscal policy, mainly those focused on the correction of the fiscal disequilibria, must take into account the origin of these disequilibria [...] and the evolution in the short and medium-term of the rest of budgetary items in order to design the correct intensity of the fiscal consolidation (or impulse) measures.

Taking this into account, the tax administration of high-income inequality countries might reduce income inequality in order to avoid that fiscal deficits may harm the economy in the future. Both high levels of income inequality and fiscal deficits provoke banking crises. In the case of a low-income inequality country, fiscal deficit seems to lead to almost no financial crisis risk, being a positive and statistically but no economic significant impact due to its low magnitude. In this case, fiscal policies could be focused in other additional issues.

\section{Concluding Remarks and Further Research}

This paper analyzes the impact of inequality on banking crunches and provides policy measures related with fiscal consolidation to decrease the risk of banking crises. Using a large sample of countries and years, a robust significance of the positive influence of the interaction of public deficit and income inequality on banking crises is found, corroborating previous theoretical frameworks and arguments of the post-Keynesianism and others. The contributions of the paper are the following. First, a positive impact of inequality and public deficit, separately, on banking crises is obtained by the estimation of a population-averaged panel logit probability model. Second, policy measures useful for law- and policy-makers are provided. Countries with high levels of income inequality might increase the budget surplus to avoid crises, or reduce the level of inequality allowing so future fiscal deficits with almost no impact on financial crises; whilst in economies with low levels of income inequality, fiscal consolidation seems to produce no 
PEÑA Income Inequality and Fiscal Consolidation

economic effect on banking crisis. The reason may be that households of countries with high income inequality are also highly indebted, and fiscal consolidation is necessary for prevent from possible banking crashes due to defaults and bad debts, and to rescue banks before a banking crisis starts.

Further research would include topics that overweight the purpose of this paper but would also be interesting. For instance, using an alternative dependent variable, GDP, to check not only the correlation with the target variables, but also the Granger-causality. Another extension of this paper, which exceeds our target, was to check the independency of Central Banks by studying whether the impact of the interaction between public deficits and monetary policy, measured by the lending interest rate, is insignificant in the impact on credit loan expansions and GDP.

\section{Appendix: discarded econometric specifications and additional robustness checks}

In this appendix other specifications of the model are shown, used to check the robustness and consistency of the results, or discarded due to its lower explanatory power compared to the chosen models. In the checks there is also a check of the potential endogeneity of the dependent variable, dynamic estimations in GMM System in addition to the control of endogeneity and dynamicity of models (V, VI) of Table 5. Econometric models are estimated using the two-step System GMM method (Arellano and Bover, 1995 and Blundell and Bond, 1998). The main reason for choosing this methodology among others is the better treatment of the endogenous bias than other methods, its dynamicity and the efficiency of its estimators. The specification of the GMM models is as follows:

$$
\operatorname{crisis}_{i, t}=\alpha * \operatorname{crisis}_{i, t-1}+\beta * \operatorname{control}_{i, t}+\varepsilon_{i, t}
$$

Where $\mathrm{i}=1, \ldots, \mathrm{N}$ and $\mathrm{t}=1, \ldots, \mathrm{T}$; where $\mathrm{T}=52$ is the total of temporal periods, the total of countries is $\mathrm{N}=35$, the dependent variable is the same as the other models, control now can also include macro and banking variables and institutional factors, alpha and beta are the coefficients of the variables, $\varepsilon_{i, t}$ is the error term. The previous models were designed considering mainly policy measures, i.e.: variables that the government could modify in a relative short term, while institutional factors can be modified by the authorities in the long term, and finally, the macro and banking factors are less manageable for the policymakers.

Main characteristics of the variables are summarized in Table 6 . The new variables are obtained from the World Bank Data ${ }^{4}$, with the exceptions of publicdebt, from the IMF database,

${ }^{4}$ https://databank.worldbank.org/home.aspx 
Review of Economic Analysis 13 (2021) 89-114

Table 6. Summary Statistics of the Additional Variables Included in the Appendix

\begin{tabular}{|c||c|c|c|c|c|}
\hline Variable & Observations & Mean & $\begin{array}{c}\text { Standard } \\
\text { Deviation }\end{array}$ & Minimum & Maximum \\
\hline \hline gdppcgr & 1587 & 2.651 & 3.630 & -31.178 & 17.557 \\
\hline Inc2 & 1485 & 24.927 & 2.348 & 18.612 & 31.198 \\
\hline capital & 440 & 7.077 & 2.455 & 2.700 & 17.400 \\
\hline liquidity & 425 & 7.839 & 9.143 & 0.230 & 60.943 \\
\hline inflation & 1518 & 11.162 & 39.335 & -4.480 & 1058.374 \\
\hline lexpect & 1869 & 70.397 & 5.262 & 43.244 & 87.700 \\
\hline depend & 1872 & 54.615 & 9.780 & 37.107 & 101.792 \\
\hline instq & 490 & $1.26 \mathrm{E}+00$ & $4.16 \mathrm{E}-01$ & $-1.15 \mathrm{E}-01$ & $2.08 \mathrm{E}+00$ \\
\hline rulelaw & 504 & 1.177 & 0.644 & -0.759 & 2.000 \\
\hline corruption & 504 & 1.197 & 0.859 & -0.820 & 2.586 \\
\hline publicdebt & 1518 & 48.741 & 34.883 & 1.717 & 289.554 \\
\hline directtax & 577 & 26.992 & 12.929 & 6.425 & 66.715 \\
\hline NPLs & 192 & 4.605 & 4.833 & 0.082 & 24.988 \\
\hline core & 1872 & 0.222 & 0.416 & 0.000 & 1.000 \\
\hline
\end{tabular}

and are composed by gdppcgr, which is the rate of growth of the per capita GDP in percentage, $\operatorname{lnc} 2$, which is the credit provided by the financial sector to the rest of the private sector, expressed in logarithm and lagged to year to avoid potential simultaneously and endogenously problems. The variable capital is the ratio of bank capital to assets and shows the share of bank capital and reserves to total assets expressed in percentage, variable liquidity is the ratio of bank liquid reserves over total bank assets, the variable inflation is measured as the consumer price index. The previous variables are considered as macroeconomic and banking country-specific variables. The variable NPLs are the bank nonperforming loans over the total of gross loans in percentage.

The variable core includes countries with very tight fiscal schedules. Regarding the institutional variables, lexpect is the life expectancy at birth of males measured in years, the variable depend is the age dependency ratio, measured as the proportion of dependents (people younger than 15 or older than 64 ) over the total working-age population (people between 1564). The variable instq is the index of regulatory quality and captures "perceptions of the ability of the government to formulate and implement sound policies and regulations that permit and promote private sector development". It ranges from approximately -2.5 to 2.5 . The variable corruption is the control of corruption index and measures "perceptions of the extent to which public power is exercised for private gain, including both petty and grand forms of corruption, as well as "capture" of the state by elites and private interests". It also ranges roughly from -2.5 
PEÑA Income Inequality and Fiscal Consolidation

to 2.5. The variable publicdebt is the public debt over GDP and is the gross general government debt to GDP expressed in percentage. Finally, the directtax variable reflects the taxes on income, profits and capital gains as percentage of revenue.

Table 7 shows the two System GMM models estimated for the above variables, i.e.: the policy factors, the first one with all the variables and the second one is the reduced model after the eliminating-procedure. Finally, Model (III) is the same as (II) but estimated in static logit model. Finally, the variable NPLs has been regressed in level and with lags, but this variable

Table 7. Additional Models with Policy Factors and NPLs

\begin{tabular}{|c|c|c|c|c|c|}
\hline crisis & $(I)$ & (II) & (III) & $(I V)$ & $(V)$ \\
\hline \multirow[t]{2}{*}{$\operatorname{lag}$} & $0.736 * * *$ & $0.699 * * *$ & & $0.733 * * *$ & $0.726 * * *$ \\
\hline & 0.000 & 0.000 & & 0.000 & 0.000 \\
\hline \multirow[t]{2}{*}{ balance } & -0.001 & & & & \\
\hline & 0.767 & & & & \\
\hline \multirow[t]{2}{*}{ terms } & $-5.91 \mathrm{E}-15$ & & & & \\
\hline & 0.471 & & & & \\
\hline \multirow[t]{2}{*}{$e x$} & 0.0002 & & & & \\
\hline & 0.547 & & & & \\
\hline \multirow[t]{2}{*}{ surplus } & $0.095 *$ & $0.088 * * *$ & 0.109 & & \\
\hline & 0.074 & 0.008 & 0.74 & & \\
\hline \multirow[t]{2}{*}{ lerner } & $-1.045 * * *$ & $-1.381 * * *$ & -0.599 & & \\
\hline & 0.000 & 0.000 & 0.818 & & \\
\hline \multirow[t]{2}{*}{ dist } & -0.026 & & & & \\
\hline & 0.418 & & & & \\
\hline \multirow[t]{2}{*}{ gini2 } & $0.018^{*}$ & $0.016 * * *$ & $-0.061 * * *$ & & \\
\hline & 0.083 & 0 & 0.001 & & \\
\hline \multirow[t]{2}{*}{ surplusgini2 } & $-0.003^{*}$ & $-0.003 * * *$ & -0.013 & & \\
\hline & 0.076 & 0.009 & 0.174 & & \\
\hline \multirow[t]{2}{*}{ NPLS } & & & & -0.004 & \\
\hline & & & & 0.421 & \\
\hline \multirow[t]{2}{*}{ NPLs $t-1$} & & & & & -0.004 \\
\hline & & & & & 0.288 \\
\hline No observations & 167 & 264 & 264 & 188 & 188 \\
\hline No groups & 28 & 34 & 34 & 31 & 31 \\
\hline $\mathrm{AIC}^{\mathrm{a}}$ & & & 258.589 & & \\
\hline $\mathrm{BIC}^{\mathrm{a}}$ & & & 276.469 & & \\
\hline Sargan (p-value) & 0.132 & 0.929 & & & \\
\hline A-B (p-value order $1 / 2)$ & $0 / 0.754$ & $0 / 0.933$ & & & \\
\hline No of instruments & 80 & 93 & & 65 & 71 \\
\hline R2 & 0.1437 & 0.1558 & & 0 & 0.012 \\
\hline Wald & 238.67 & 727.86 & 45.08 & & \\
\hline Wald p-value & 0.000 & 0.000 & 0.000 & & \\
\hline
\end{tabular}


has only a few observations and provoked problems in the estimations, furthermore, its significativity and explanatory power was low as Models (IV) and (V) show.

Next, Tables are 8 and 9 where the country specific (banking and macro) and institutional factors are included as explanatory variables, respectively. In Table 10 the "complete" or "final" model using all the significant variables of the previous reduced models are included jointly. Models (I) and (II) of each table are the respective GMM System models as in Table 7 but with the new independent variables, Model (III) is also the same model as (II) but estimated in logit, and Models (IV) and (V) are similar to the Models (III) and (IV) of Table 5, in which all the variables used initially for each table as factors are included (Models IV of Tables 8-10) and estimated in logit, while Models (V) are the reduced form of the previous one after the eliminating-procedure.

Table 8. Models with Macro and Banking Factors

\begin{tabular}{|c|c|c|c|c|c|}
\hline crisis & (I) & (II) & (III) & (IV) & $(V)$ \\
\hline \multirow[t]{2}{*}{ lag } & $0.427 * * *$ & $0.677 * * *$ & & & \\
\hline & 0.000 & 0.000 & & & \\
\hline \multirow[t]{2}{*}{ gdppcgr } & $-0.013 * *$ & $-0.011 * * *$ & $-0.231 * * *$ & $-0.269 * * *$ & $-0.275^{* * *}$ \\
\hline & 0.048 & 0.005 & 0.002 & 0.000 & 0.000 \\
\hline \multirow{2}{*}{$\ln c 2$} & 0.006 & & & -0.0208811 & $-0.058^{* * *}$ \\
\hline & 0.548 & & & $0.518^{* *}$ & 0.000 \\
\hline \multirow[t]{2}{*}{ capital } & -0.0490 & & & 0.010 & \\
\hline & 0.169 & & & 0.935 & \\
\hline \multirow[t]{2}{*}{ surplus } & $0.096^{* *}$ & 0.048 & 0.108 & -0.346 & $-0.183 * * *$ \\
\hline & 0.022 & 0.093 & 0.285 & 0.309 & 0.000 \\
\hline \multirow[t]{2}{*}{ liquidity } & 0.011 & & & -0.057 & \\
\hline & 0.317 & & & 0.211 & \\
\hline \multirow{2}{*}{ inflation } & $0.038^{* * *}$ & 0.000 & $0.003 * * *$ & 0.042 & \\
\hline & 0.000 & 0.046 & 0.000 & 0.660 & \\
\hline \multirow[t]{2}{*}{ gini2 } & 0.015 & 0.006 & $-0.038 * * *$ & -0.013 & \\
\hline & 0.129 & 0.002 & 0.000 & $0.680^{* * *}$ & \\
\hline \multirow[t]{2}{*}{ surplusgini2 } & $-0.004 * * *$ & -0.002 & $-0.009 * *$ & 0.004 & \\
\hline & 0.007 & 0.098 & 0.013 & 0.704 & \\
\hline No observations & 204 & 297 & 297 & 204 & 521 \\
\hline No groups & 29 & 35 & 35 & 29 & 36 \\
\hline $\mathrm{AIC}^{\mathrm{a}}$ & & & 264.197 & 192.535 & 386.024 \\
\hline $\mathrm{BIC}^{\mathrm{a}}$ & & & 286.36 & 228.295 & 403.047 \\
\hline Sargan (p-value) & 0.333 & 0.905 & & & \\
\hline A-B (p-value order & $0 / 0.595$ & $0 / 0.58$ & & & \\
\hline No of instruments & 77 & 100 & & & \\
\hline $\mathrm{R} 2$ & 0.4374 & 0.2425 & & & \\
\hline Wald & 831.63 & 2218.47 & 197.87 & 45.86 & 136.51 \\
\hline Wald p-value & 0.000 & 0.000 & 0.000 & 0.000 & 0.000 \\
\hline
\end{tabular}


PEÑA Income Inequality and Fiscal Consolidation

Table 9. Models with Institutional Factors

\begin{tabular}{|c|c|c|c|c|c|}
\hline crisis & $(I)$ & (II) & (III) & $(I V)$ & $(\mathrm{V})$ \\
\hline \multirow[t]{2}{*}{$\operatorname{lag}$} & $0.611 * * *$ & $0.694 * * *$ & & & \\
\hline & 0.000 & 0.000 & & & \\
\hline \multirow[t]{2}{*}{ lexpect } & 0.005 & & & -0.037 & $-0.030 * *$ \\
\hline & 0.709 & & & 0.497 & 0.064 \\
\hline \multirow[t]{2}{*}{ depend } & -0.012 & & & 0.022 & \\
\hline & 0.574 & & & 0.817 & \\
\hline \multirow[t]{2}{*}{ instq } & 0.2058 & & & $-2.715 * *$ & $-2.201 * *$ \\
\hline & 0.394 & & & 0.044 & 0.018 \\
\hline \multirow[t]{2}{*}{ rulelaw } & 0.354 & $0.613 * * *$ & 0.430 & $4.192 * *$ & $3.703 * *$ \\
\hline & 0.314 & 0.002 & 0.716 & 0.029 & 0.041 \\
\hline \multirow[t]{2}{*}{ corruptcontrol } & $-0.544 * * *$ & $-0.400 * *$ & -1.236 & $-1.907 *$ & $-1.746^{*}$ \\
\hline & 0.000 & 0.011 & 0.264 & 0.087 & 0.087 \\
\hline \multirow[t]{2}{*}{ publicdebt } & 0.004 & & & 0.005 & \\
\hline & 0.304 & & & 0.715 & \\
\hline \multirow[t]{2}{*}{ directtax } & -0.006 & & & 0.013 & \\
\hline & 0.590 & & & 0.582 & \\
\hline \multirow[t]{2}{*}{ surplus } & $0.072 * *$ & $0.084 * *$ & -0.177 & -0.255 & $-0.293 * * *$ \\
\hline & 0.025 & 0.012 & 0.627 & 0.461 & 0.000 \\
\hline \multirow[t]{2}{*}{ gini2 } & 0.004 & & & -0.012 & \\
\hline & 0.687 & & & 0.745 & \\
\hline \multirow[t]{2}{*}{ surplusgini2 } & $-0.002 *$ & $-0.003 * *$ & -0.001 & 0.000 & \\
\hline & 0.053 & 0.022 & 0.948 & 0.977 & \\
\hline \multirow[t]{2}{*}{ core } & 0.981 & & & $1.824 * *$ & $1.905 * * *$ \\
\hline & 0.269 & & & 0.010 & 0.000 \\
\hline No observations & 251 & 254 & 258 & 251 & 412 \\
\hline No groups & 33 & 34 & 34 & 33 & 35 \\
\hline $\mathrm{AICa}$ & & & 271.542 & 252.6962 & 336.656 \\
\hline $\mathrm{BICa}$ & & & 289.307 & 295.02 & 364.803 \\
\hline Sargan (p-value) & 0.9593 & 0.999 & & & \\
\hline $\begin{array}{c}\text { A-B (p-value order } \\
1 / 2)\end{array}$ & $0 / 0.885$ & $0 / 0.981$ & & & \\
\hline No of instruments & 88 & 85 & & & \\
\hline R2 & 0.464 & 0.2492 & & & \\
\hline Wald & 1442.64 & 1673.97 & 15.87 & 71.61 & 104.56 \\
\hline Wald p-value & 0.000 & 0.000 & 0.003 & 0.000 & 0.000 \\
\hline
\end{tabular}


Table 10. Models with Final Factors Among Other Models After the Eliminating-Procedure

\begin{tabular}{|c|c|c|c|c|c|}
\hline crisis & $(I)$ & (II) & (III) & $(I V)$ & $(V)$ \\
\hline \multirow[t]{2}{*}{$\operatorname{lag}$} & $0.709 * * *$ & $0.684 * * *$ & & & \\
\hline & 0.000 & 0.000 & & & \\
\hline \multirow[t]{2}{*}{ lexpect } & -0.007 & & & $-0.318 * * *$ & \\
\hline & 0.708 & & & 0.003 & \\
\hline \multirow[t]{2}{*}{ instq } & -0.1478346 & & & 4.628 & $-1.174 * * *$ \\
\hline & 0.588 & & & 0.201 & 0.000 \\
\hline \multirow[t]{2}{*}{ rulelaw } & $0.611 * * *$ & $0.632 * * *$ & $3.508 * *$ & 4.192779 & \\
\hline & 0.036 & 0.000 & 0.025 & 0.150 & \\
\hline \multirow[t]{2}{*}{ corruptcontrol } & $-0.397 * * *$ & $-0.444 * * *$ & $-3.659 * *$ & $-4.688 * * *$ & \\
\hline & 0.002 & 0.000 & 0.011 & 0.000 & \\
\hline \multirow[t]{2}{*}{ gdppcgr } & $-0.013 * * *$ & $-0.010 * *$ & -0.119 & -0.206 & $-0.267 * *$ \\
\hline & 0.003 & 0.010 & 0.238 & 0.175 & 0.001 \\
\hline \multirow[t]{2}{*}{$\ln c 2$} & -0.003 & & & 0.412 & \\
\hline & 0.951 & & & 0.116 & \\
\hline \multirow[t]{2}{*}{ inflation } & $0.027 *$ & $0.018^{*}$ & 0.045 & 0.181 & \\
\hline & 0.070 & 0.060 & 0.390 & 0.222 & \\
\hline \multirow[t]{2}{*}{ balance } & $0.011^{*}$ & $0.010^{*}$ & $0.102 * *$ & $0.279 * * *$ & $0.063 * * *$ \\
\hline & 0.079 & 0.059 & 0.043 & 0.009 & 0.002 \\
\hline \multirow[t]{2}{*}{$e x$} & -0.0002 & $-0.0005 * * *$ & $-0.011^{*}$ & -0.001 & \\
\hline & 0.362 & 0.000 & 0.054 & 0.269 & \\
\hline \multirow[t]{2}{*}{ surplus } & 0.094 & $0.111 * *$ & -0.148 & 0.544 & \\
\hline & 0.105 & 0.019 & 0.611 & 0.242 & \\
\hline \multirow[t]{2}{*}{ gini2 } & 0.013 & & & $0.112 * *$ & \\
\hline & 0.305 & & & 0.033 & \\
\hline \multirow[t]{2}{*}{ surplusgini2 } & -0.002 & $-0.003 *$ & 0.004 & -0.020 & $-0.007 * * *$ \\
\hline & 0.216 & 0.057 & 0.645 & 0.165 & 0.000 \\
\hline \multirow[t]{2}{*}{ core } & 0.593 & & & $2.61 * * *$ & $0.962 *$ \\
\hline & 0.396 & & & 0.000 & 0.080 \\
\hline No observations & 149 & 156 & 156 & 149 & 254 \\
\hline No groups & 24 & 25 & 25 & 24 & 33 \\
\hline $\mathrm{AICa}$ & & & 119.107 & 102.660 & 223.948 \\
\hline $\mathrm{BICa}$ & & & 146.556 & 144.716 & 245.172 \\
\hline Sargan (p-value) & 0.9113 & 0.9705 & & & \\
\hline $\begin{array}{c}\text { A-B (p-value order } \\
1 / 2)\end{array}$ & $0 / 0.6729$ & $0 / 0.4223$ & & & \\
\hline crisis & (I) & (II) & (III) & $(I V)$ & $(V)$ \\
\hline No of instruments & 75 & 75 & & & \\
\hline $\mathrm{R} 2$ & 0.335 & 0.3117 & & & \\
\hline Wald & $1.75 \mathrm{E}+06$ & 10114.56 & 14.38 & 217.23 & 59.63 \\
\hline Wald p-value & 0.000 & 0.000 & 0.000 & 0.000 & 0.000 \\
\hline
\end{tabular}


PEÑA Income Inequality and Fiscal Consolidation

From the previous models, it is worth to mention that the Arellano-Bond (A-B) test has only been possible to be estimated with the correspondent model in GMM in differences and the R2 is obtained from the correspondent static pool Ordinary Least Squares (OLS) model. In addition, it is well known that logit models are one of the best models in predicting crises. Table 11 presents the non-nest test of the estimated models, showing the AIC and BIC of the "finalist" models (i.e.: the logit model of each kind of factors, including the final or complete models, with the lowest indicators for each type of variables), in order to show why the chosen model and presented in Section 5 is the definitive. As this Table shows, the Model (III) of Table 5 is chosen because of its highest explanatory power among the other models. Going further, Model (V) of Table 5, based on the previous model but with the inclusion of additional variables, shows the lowest indicator among all the models $(\mathrm{AIC}=108, \mathrm{BIC}=140)$.

While Model 10(III) presented lower AIC than in Model 5(V), the last model was chosen because of its lower BIC and less number of explanatory variables than 10(III) and also than the rest of models. Finally, in the definitive Model (V) of Table 5 there is an additional test in order to ensure that there is no evidence of endogeneity. The Durbin-Wu-Hausman (DWH) test ${ }^{5}$ is performed to check it. This test consists on performing an additional specification including the potential endogenous variables (in this case, to check if surplusgini2 and crisis

Table 11. Summary of the Explanatory Power of the Models

\begin{tabular}{|c|c|c|c|}
\hline Model & $5(\mathrm{III})$ & $8(\mathrm{IV})$ & $9(\mathrm{IV})$ \\
\hline Table & 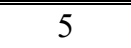 & 8 & 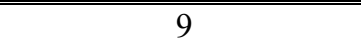 \\
\hline Factors & Policy & $\begin{array}{l}\text { Macro and } \\
\text { banks }\end{array}$ & Institutional \\
\hline $\mathrm{AIC}$ & 119.574 & 192.535 & 252.696 \\
\hline $\mathrm{BIC}$ & 144.519 & 228.295 & 295.020 \\
\hline No of explanatory variables & 8 & 8 & 11 \\
\hline Model & 10 (III) & 5(III) & $5(\mathrm{~V})$ \\
\hline Table & 10 & $\overline{5}$ & $\overline{5}$ \\
\hline Factors & Mixture & Chosen model & $\begin{array}{c}\text { Augmented chosen model } \\
\text { (definitive) }\end{array}$ \\
\hline $\mathrm{AIC}$ & 102.660 & 119.574 & 108.346 \\
\hline $\mathrm{BIC}$ & 144.716 & 144.519 & 139.526 \\
\hline No of explanatory variables & 13 & 8 & 10 \\
\hline
\end{tabular}

\footnotetext{
${ }^{5}$ https://www.stata.com/support/faqs/statistics/durbin-wu-hausman-test/
} 
present endogenous behavior) and the residuals of the model, and regress them to another variable as dependent. If the coefficient of the residues is significantly distinct from zero, then there is evidence of endogeneity. The DWH test gives the following result for the Model (V) of Table 5, a Chi of 0.59 and a p-value of 0.4424 , then the residuals are not significantly distinct from zero, and then this suggests that there is not endogeneity bias. Furthermore, the same Model (V) has been estimated but with an instrumental variables probit model, which compare the full sample with the potential endogenous variable (the instrumented variable) with the reduced sample with the instruments, and checks whether the instrumented variable was really endogenous. The lending interest rate is used as instrumental variable because of its significative correlation with the instrumented variable (surplusgini2), obtaining a Wald test of the exogeneity of the instrumented variable as null hypothesis with a p-value of higher than 0.6 , accepting the null hypothesis of the exogeneity of surplusgini2 In addition, other specifications have been tried to use, but due to the insignificantly change of the results; they have been avoided to expose. Some examples include models with the interaction between income inequality and growth and tax variables, or the elimination of the core countries or the use of countries of the South of Europe (Spain, Portugal, Italy and Greece).

\section{References}

Ağca, Ş., \& Igan, D. (2019), 'Fiscal consolidations and the cost of credit', Journal of International Economics (https://www.sciencedirect.com/science/article/abs/pii/ $\underline{\text { S0022199619300534). }}$

Agnello, Luca, and Ricardo M. Sousa. (2012), 'How do banking crises impact on income inequality?' Applied Economics Letters, 19(15), 1425-1429 (https://www.tandfonline.com/ doi/abs/10.1080/13504851.2011.631885).

Arellano, M. and Bover, O. (1995), 'Another Look at the Instrumental Variable Estimation of Error-Components Models', Journal of Econometrics, 68: 29-51.

Atkinson, Anthony B., and Salvatore Morelli. (2011), 'Economic crises and Inequality.' UNDP-HDRO Occasional Papers, (2011/6) (https://papers.ssrn.com/sol3/ papers.cfm?abstract id $=2351471$ ).

Ball, L. M., Furceri, D., Leigh, M. D., \& Loungani, M. P. (2013), 'The distributional effects of fiscal consolidation' (No. 13-151), International Monetary Fund (https://pdfs.semanticscholar.org/aaf0/a872d71eb08c97c42b3b1e21d1d759c7acef.pdf).

Balteanu, I., \& Erce, A. (2018), 'Linking bank crises and sovereign defaults: Evidence from emerging markets', IMF Economic Review, 66(4), 617-664 (https://ink.springer.com/ article/10.1057/s41308-018-0066-4). 
PEÑA Income Inequality and Fiscal Consolidation

Barba, Aldo, and Massimo Pivetti. (2009), 'Rising household debt: Its causes and macroeconomic implications-a long-period analysis.' Cambridge Journal of Economics, 33(1), 113-137 (https://academic.oup.com/cje/article-abstract/33/1/113/1700026).

Bazillier, Rémi, and Jérôme Hericourt, (2017), 'The circular relationship between inequality, leverage, and financial crises', Journal of Economic Surveys, 31(2), 463-496 (https://onlinelibrary.wiley.com/doi/abs/10.1111/joes.12150).

Beck, T., Demirguc,-Kunt, A., Levine, R., (2006), 'Bank concentration, competition and crises: first results', J. Bank. Finance 30, 1581-1603.

Beck, Thorsten, Asli Demirgüç-Kunt, and Ross Levine. (2006), 'Bank concentration, competition, and crises: First results.' Journal of Banking \& Finance, 30(5), 1581-1603 (https://www.sciencedirect.com/science/article/abs/pii/S0378426605001044).

Bianco, A., \& Sardoni, C. (2018), 'Banking theories and macroeconomics', Journal of Post Keynesian Economics, 41(2), 165-184.

Blundell, R. \& Bond, S. (1998), 'Initial Conditions and Moment Restrictions in Dynamic Panel Data Models', Journal of Econometrics, 87, 115-43.

Bordo, Michael D., and Christopher M. Meissner. (2012), 'Does inequality lead to a financial crisis?' Journal of International Money and Finance, 31(8), 2147-2161 (https://www.sciencedirect.com/science/article/pii/S0261560612000976).

Burman, Leonard E., et al. (2010), 'Catastrophic budget failure.' National Tax Journal, 63(3), 561-584 (https://www.taxpolicycenter.org/sites/default/files/alfresco/publication-pdfs/ 1001564-Catastrophic-Budget-Failure.PDF).

Büyükkarabacak, Berrak, and Neven T. Valev. (2010), 'The role of household and business credit in banking crises.' Journal of Banking \& Finance, 34(6), 1247-1256 (https://www.sciencedirect.com/science/article/abs/pii/S0378426609003197).

Dabrowski, J. J., Beyers, C., \& de Villiers, J. P. (2016), 'Systemic banking crisis early warning systems using dynamic Bayesian networks', Expert systems with applications, 62, 225-242.

Demirgüç-Kunt, Asli, and Enrica Detragiache. (1998), 'The Determinants of Banking Crises in Developing and Developed Countries.' IMF Economic Review, 45(1), 81-109 (https://link.springer.com/article/10.2307/3867330).

European Banking Authority (2020), Risk Dashboard Data As Of Q2 2020.

Evangelos, V. and Samitas, A. (2020), 'Value at Risk, Legislative Framework, Crises, and Procyclicality: what goes wrong?', Review of Economic Analysis, forthcoming.

Fell, J. P., Grodzicki, M., Metzler, J., \& O'Brien, E. (2018). Non-performing loans and euro area bank lending behaviour after the crisis. Revista de estabilidad financiera. $\mathrm{N}^{\circ} 35$ (noviembre 2018), p. 7-28 (https://repositorio.bde.es/bitstream/123456789/11241/1/ Non performing loans espanol.pdf) 
Ferreiro, Jesús, Catalina Gálvez, Carmen Gómez, and Ana González. (2016), 'Bank rescues and fiscal policy in the European Union during the great recession.' Panoeconomicus, 63(2), 211-230 (http://panoeconomicus.org/index.php/jorunal/article/view/384).

Frankel, J., \& Saravelos, G. (2012). Can leading indicators assess country vulnerability? Evidence from the 2008-09 global financial crisis. Journal of International Economics, 87(2), 216-231.

Galbraith, James K. (2012), 'Inequality and Instability: A Study of the World Economy Just Before the Great Crisis.' Oxford University Press.

Gavin, Michael, and Ricardo Hausmann. (1996), 'The Roots of Banking Crises: The Macroeconomic Context.' In Hausmann, Ricardo, and Liliana Rojas-Suárez (Ed.), Banking crises in Latin America, Inter-American Development Bank, Washington, D.C., 25-63.

Goldstein, M., \& Turner, P. (1996), 'Banking crises in emerging economies: origins and policy options', Trade Currencies and Finance, 301-363.

Hardy, Daniel C., and Ceyla Pazarbaşioğlu. (1999), 'Determinants and leading indicators of banking crises: Further evidence.' IMF Economic Review, 46(3), 247-258 (https://link.springer.com/article/10.2307/3867642).

Kauko, K. (2014). How to foresee banking crises? A survey of the empirical literature. Economic Systems, 38(3), 289-308.

Keeley, M.C. (1990), 'Deposit insurance, risk and market power in banking', Am. Econ. Rev. $80,1183-1200$.

Kirschenmann, Karolin, Tuomas Malinen, and Henri Nyberg. (2016), 'The risk of financial crises: Is there a role for income inequality?' Journal of International Money and Finance, 68, 161-180 (https://www.sciencedirect.com/science/article/pii/S0261560616300894).

Knutsen, S. and Sjögren, H. (2009), 'Institutional Clash and Financial Fragility. An Evolutionary Model of Banking Crises', MPRA Paper No. 13133, 5, January 2009 (http://mpra.ub.uni-muenchen.de/13133/).

Kumhof, Michael, Claire Lebarz, Romain Ranciere, Alexander W. Richter and Nathaniel A. Throckmorton. (2012), 'Income inequality and current account imbalances', IMF Working Paper WP/12/8 (https://nathrockmorton.people.wm.edu/Papers/KLRRT Inequality.pdf).

Kumhof, Michael, Romain Rancière, and Pablo Winant. (2015), 'Inequality, leverage, and crises.' The American Economic Review, 105(3), 1217-1245 (https://www.aeaweb.org/ articles?id=10.1257/aer.20110683).

Laeven, L. (2011), 'Banking crises: A review', Annu. Rev. Financ. Econ., 3(1), 17-40.

Laeven, L., \& Valencia, F. (2020). Systemic Banking Crises Database II. IMF Economic Review, 1-55.

Laidler, D. (2009), 'Financial stability, monetarism and the Wicksell connection', Review of Economic Analysis, 1(1), 60-79 (https://openjournals.uwaterloo.ca/index.php/ rofea/article/view/1479). 
PEÑA Income Inequality and Fiscal Consolidation

Lainà, P., Nyholm, J., \& Sarlin, P. (2015), 'Leading indicators of systemic banking crises: Finland in a panel of \{EU\} countries', Review of Financial Economics, 24, 18-35. (http://www.sciencedirect.com/science/article/pii/S1058330014000512).

Mayer, Thierry, and Soledad Zignago. (2011), 'Notes on CEPII's distances measures: the GeoDist Database', CEPII Working Paper 2011-25 (https://papers.ssrn.com/sol3/papers.cfm?abstract id=1994531).

Morelli, Salvatore, and Anthony B. Atkinson. (2015), 'Inequality and crises revisited'. Economia Politica, 32(1), 31-51 (https://link.springer.com/article/10.1007/s40888-015-

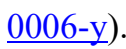

Neuhaus, John M., John D. Kalbfleisch, and Walter W. Hauck. (1991), 'A comparison of cluster-specific and population averaged approaches for analyzing correlated binary data.' International Statistical Review 59(1), 25-35 (https://www.jstor.org/stable/1403572).

Noy, I., (2004), 'Financial liberalization, prudential supervision and the onset of banking crises', Emerg. Mark. Rev. 5, 341-359.

Palley, Thomas I. (2012), 'From Financial Crisis To Stagnation: The Destruction of Shared Prosperity and the Role of Economics.' Cambridge University Press.

Peña, Guillermo (2016). The determinants of banking crises: Further evidence, MPRA WP 70093 (https://mpra.ub.uni-muenchen.de/70093/).

Peña, Guillermo (2017a): 'Income inequality, fiscal consolidation and banking crises'. In the XXIV Encuentro de Economía Pública. Universidad de Castilla-La Mancha, 2017. p. 58 (https://dialnet.unirioja.es/servlet/articulo?codigo $=6121526$ ).

Peña, Guillermo (2017b): 'Money, lending and banking crises', Economic Papers: A journal of applied economics and policy, 36(4), 444-458 (https://onlinelibrary.wiley.com/ doi/abs/10.1111/1759-3441.12195).

Peña, Guillermo (2020): 'VAT experience as an influence on banking crises', National Accounting Review, 2(1): 53-65 (https://www.aimspress.com/article/10.3934/ NAR.2020003/Related.html).

Pereira Pedro, C., Ramalho, J. J., and Vidigal da Silva, J. (2018), 'The main determinants of banking crises in OECD countries', Review of World Economics, 154(1), 203-227 (https://link.springer.com/article/10.1007/s10290-017-0294-0).

Rajan, Raghuram. (2010), 'Fault Lines.' Princeton University Press, Princeton, NJ.

Rathore, A. S. (2020), 'EBA's Capital Exercise and Technical Efficiency of the Banks', Review of Economic Analysis, 12(1), forthcoming (https://openjournals.uwaterloo.ca/index.php/ rofea/article/view/1774).

Reich, Robert B. (2010), 'Aftershock: The Next Economy and America's Future.' Alfred A. Knopf, New York.

Reinhart, C. M. (2002), 'Default, currency crises, and sovereign credit ratings. the world bank economic review', 16(2), 151-170. 
Roine, Jesper, Jonas Vlachos, and Daniel Waldenström (2009), 'The long-run determinants of inequality: What can we learn from top income data?' Journal of Public Economics, 93(78), 974-988 (https://www.sciencedirect.com/science/article/abs/pii/S0047272709000383).

Rose, Andrew K., and Mark M. Spiegel (2010), 'Cross-Country Causes and Consequences of the 2008 Crisis: International Linkages and American Exposure.' Pacific Economic Review, 15(3), 340-363 (https://onlinelibrary.wiley.com/doi/abs/10.1111/j.14680106.2010.00507.x).

Rose, Andrew K., and Mark M. Spiegel (2011), 'Cross-country causes and consequences of the crisis: An update', European Economic Review, 55(3), 309-324 (https://www.sciencedirect.com/science/article/pii/S0014292110001285).

Roy, Saktinil, and David M. Kemme (2012), 'Causes of banking crises: Deregulation, credit booms and asset bubbles, then and now.' International Review of Economics \& Finance, 24, 270-294 (https://www.sciencedirect.com/science/article/pii/S1059056012000299).

Soral, H. B., İşcan, T. B., \& Hebb, G. (2006). Fraud, banking crisis, and regulatory enforcement: Evidence from micro-level transactions data. European Journal of Law and Economics, 21(2), 179-197.

Stockhammer, Engelbert (2013), 'Rising inequality as a cause of the present crisis.' Cambridge Journal of Economics, 39(3), 935-958 (https://academic.oup.com/cje/article-abstract/ 39/3/935/1713529).

Van Treeck, Till (2014), 'Did inequality cause the US financial crisis?' Journal of Economic Surveys, 28(3), $421-448$ (https://onlinelibrary.wiley.com/doi/abs/10.1111/joes.12028).

Wisman, Jon D (2013), 'Wage stagnation, rising inequality and the financial crisis of 2008.' Cambridge Journal of Economics, 37(4), 921-945 (https://academic.oup.com/cje/articleabstract/37/4/921/1712745).

Wooldridge, Jeffrey M (2002), 'Econometric Analysis of Cross Section and Panel Data.' The MIT Press, Cambridge.

Ye, Qing, and Liyan Han (2010), 'The international propagation of shocks in international equity markets during the subprime mortgage crisis,' International Conference on Future Information Technology and Management Engineering (FITME), IEEE October (2), 468471.

Zeger, Scott L., Kung-Yee Liang, and Paul S. Albert (1988), 'Models for longitudinal data: a generalized estimating equation approach.' Biometrics, 44(4), 1049-1060 (https://www.jstor.org/stable/2531734? seq=1). 